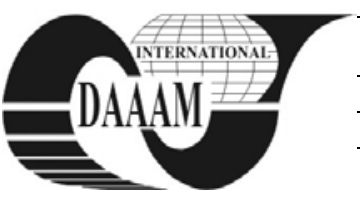

\title{
THE ASPECTS ABOUT ECONOMIC ANALYSIS AND MEASURE FOR RESTRUCTURE A COMPANY
}

\section{TENT, I[onut] D[acian]; DUMITRESCU, C[onstantin] D[an]; DUMITRESCU, E[ugenia] C[intia] I[vonne]; TRANDAFIR, N[icoleta] \& IRIMIE, S[abin] I[oan]}

\begin{abstract}
This paper aims to analyze the cost 1000 RON turnover in order to determine the possibility of restructuring the company. After analysis by the research work was developed a case study on the possibility of restructuring and modalities used for this operation, method used for this operation

Key words: financial analysis, annual turnover, forecasts
\end{abstract}

\section{INTRODUCTION}

In a general acceptance the cost is on resource expression in monetary consumption of achieving the company, or a methodological perspective, the cost can be treated as a grouping or regrouping, according to certain criteria, expenditure, combinations are so many as a construction game. So the cost is the total consumption of resources that made the company to achieve a unit of product or service.

\section{EXPENDITURE ANALYSIS BASED ON TURNOVER}

For restructure the production system are based on the analysis of turnover variation and expenses resulting from the manufacturing cycle of the company's products.

For analysis using data from account profit and loss of society in Table 1:

\begin{tabular}{|c|c|c|c|c|c|}
\hline $\begin{array}{c}\mathrm{Nr} \\
\cdot\end{array}$ & $\begin{array}{c}\text { Indica } \\
\text { toros }\end{array}$ & 2009 & 2010 & $\begin{array}{c}\text { Deviation } \\
(\Delta)\end{array}$ & $\begin{array}{c}\text { Indices } \\
(\%)\end{array}$ \\
\hline 1 & $\mathrm{~A}$ & 5343702 & 3841159 & -1502543 & 71,88 \\
\hline 2 & $\mathrm{~B}$ & 4077847 & 2346984 & -1730863 & 57,55 \\
\hline 3 & C & - & 3629244 & - & - \\
\hline 4 & $\mathrm{D}$ & & 2863394 & - & - \\
\hline 5 & $\mathrm{E}$ & 763,11 & 611 & $-152,11$ & 80,1 \\
\hline
\end{tabular}

Tab. 1. Efficiency of expenditure afferent turnover in 20092010

A -Turnover $\left(\sum \mathrm{q}_{\mathrm{i}} \cdot \mathrm{p}_{\mathrm{i}}\right)$

$\mathrm{B}$-Expenditure afferent of turnover

$\left(\sum \mathrm{q}_{\mathrm{i}} \cdot \mathrm{C}_{\mathrm{i}}\right)$

$\mathrm{C}$-Recalculated turnover

$\left(\sum \mathrm{q}_{\mathrm{i} 1} \cdot \mathrm{p}_{\mathrm{i} 0}\right)$

D -Expenditure to 1000 RON turnover

E - Expenditure afferent of recalculated turnover $\left(\sum \mathrm{q}_{\mathrm{i} 1} \cdot \mathrm{c}_{\mathrm{i} 0}\right)$.

In Figure1. I represent account indicators for profit and loss.

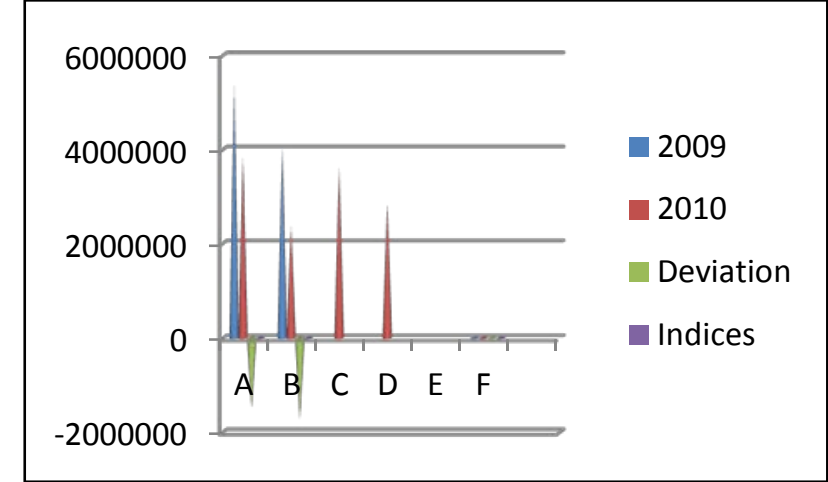

Fig.1. Graph representative of turnover and indicators for the period 2009-2010

3. THE CALCULATION MODEL OF THE INDICATOR, EXPENDITURE AT 1000 RON TURNOVER

$\mathrm{C}^{(1000)}=\left(\sum \mathrm{Ch}_{\mathrm{i}} / \sum \mathrm{CA}\right) \cdot 1000=\left(\sum \mathrm{q}_{\mathrm{i}} \cdot \mathrm{C}_{\mathrm{i}} / \sum \mathrm{q}_{\mathrm{i}} \cdot \mathrm{p}_{\mathrm{i}}\right) \cdot 1000$

Where: Chi = Expenditure at each levelcategories of activity

"i"; $\quad$ CA = turnover;

qi = quantity;

$\mathrm{ci}=$ the unit price at product " $\mathrm{i}$ ";

$\mathrm{pi}=$ The average selling price (excluding T.V.A).

a) Total change in the indicator $\left(\Delta \mathbf{C}^{\mathbf{( 1 0 0 0 )}}\right)$ : $\Delta \mathrm{C}^{(1000)}=\frac{\sum \mathrm{q}_{\mathrm{i} 1} \cdot \mathrm{c}_{\mathrm{i} 1}}{\sum_{\mathrm{i} 1} \cdot \mathrm{p}_{\mathrm{i} 1}} \cdot 1000-\frac{\sum \mathrm{q}_{\mathrm{i} 0} \cdot \mathrm{c}_{\mathrm{i} 0}}{\sum_{\mathrm{i}} \mathrm{q}_{\mathrm{i} 0} \cdot \mathrm{p}_{\mathrm{i} 0}} \cdot 1000=\mathrm{C}_{1}{ }^{(1000)}-\mathrm{C}_{0}{ }^{(1000)}$
$\Delta \mathrm{C}^{(1000)}=611-763,11=-152,11 \% \mathrm{o}$

b) Decomposition of the factors of influence:

$$
\Delta \mathrm{C}^{(1000)}=\Delta \mathrm{g}_{\mathrm{i}}+\Delta \mathrm{p}_{\mathrm{i}}+\Delta \mathrm{c}_{\mathrm{i}}
$$

c) Establishing the influence of each factor with changes on the indicator:

1. Influence change in the structure of turnover:

$$
\begin{aligned}
& \left.\quad \Delta \mathrm{g}_{\mathrm{i}}=\frac{\sum \mathrm{q}_{\mathrm{i} 1} \cdot \mathrm{c}_{\mathrm{i} 0}}{\sum \mathrm{q}_{\mathrm{i} 1} \cdot \mathrm{p}_{\mathrm{i} 0}} \cdot 1000-\frac{\sum \mathrm{q}_{\mathrm{i} 0} \cdot \mathrm{c}_{\mathrm{i} 0}}{\sum \mathrm{q}_{\mathrm{i} 0} \cdot \mathrm{p}_{\mathrm{i} 0}} \cdot 1000=\mathrm{C}^{(1000)}\right)^{-} \\
& \mathrm{C}_{0}{ }^{(1000)} \\
& \Delta \mathrm{g}_{\mathrm{i}}=(2863394 / 3629244) \cdot 1000-763,11=788,98-763,11 \\
& =25,87 \%
\end{aligned}
$$

2. Influence change in average selling prices:

$$
\mathrm{C}^{(1000)^{\prime}}, \Delta \mathrm{p}_{\mathrm{i}}=\frac{\sum \mathrm{q}_{\mathrm{i} 1} \cdot \mathrm{c}_{\mathrm{i} 0}}{\sum \mathrm{q}_{\mathrm{i} 1} \cdot \mathrm{p}_{\mathrm{i} 1}} \cdot 1000-\frac{\sum \mathrm{q}_{\mathrm{i} 1} \cdot \mathrm{c}_{\mathrm{i} 0}}{\sum \mathrm{q}_{\mathrm{i} 1} \cdot \mathrm{p}_{\mathrm{i} 0}} \cdot 1000=\mathrm{C}_{1}{ }^{(1000)^{\prime}}-
$$


$\Delta \mathrm{p}_{\mathrm{i}}=(2863394 / 3841159) \cdot 1000-788,98=745,45-$ $788,98=-43,53 \%$ o[2]

3. Influence change in unit production costs

$$
\begin{aligned}
& \quad \Delta \mathrm{c}_{\mathrm{i}}=\frac{\sum \mathrm{q}_{\mathrm{i} 1} \cdot \mathrm{c}_{\mathrm{i} 1}}{\sum \mathrm{q}_{\mathrm{i} 1} \cdot \mathrm{p}_{\mathrm{i} 1}} \cdot 1000-\frac{\sum \mathrm{q}_{\mathrm{i} 1} \cdot \mathrm{c}_{\mathrm{i} 0}}{\sum \mathrm{q}_{\mathrm{i} 1} \cdot \mathrm{p}_{\mathrm{i} 1}} \cdot 1000=\mathrm{C}_{1}{ }^{(1000)}- \\
& \mathrm{C}_{1}{ }^{(1000)}, \quad \\
& \Delta \mathrm{c}_{\mathrm{i}}=611-745,45=-134,45 \% \\
& \Delta \mathrm{C}^{(1000)}=-152,11 \% \\
& \bullet \Delta \mathrm{g}_{\mathrm{i}}=25,87 \% \\
& \bullet \Delta \mathrm{p}_{\mathrm{i}}=-43,53 \% \\
& \left.\bullet \Delta \mathrm{c}_{\mathrm{i}}=-134,45 \% \text { (Figure } 2\right)
\end{aligned}
$$

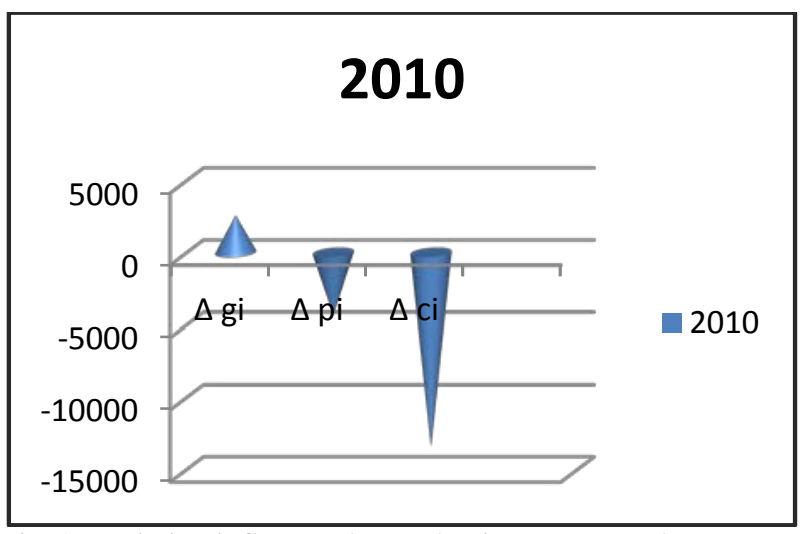

Fig. 2. Variation influence the production structure change

$\Delta g_{\mathrm{i}}=$ influence change in the structure of turnover;

$\Delta \mathrm{p}_{\mathrm{i}}=$ influence change in average selling prices;

$\Delta \mathrm{c}_{\mathrm{i}}=$ influence change in unit production costs;

Expenditure to 1000 RON turnover fell by $152.11 \%$, from $763.11 \%$ to $611 \%$, favorable situation for the company analyzed, the efficiency related of turnover expenses increased, which means that the growth rate of turnover business $[(3841159 / 5343702 \cdot 100]=71.88 \%)$ ahead of spending growth $[(3793848 / 5959413) \cdot 100]=63.66 \%$

\section{FACTORS INFLUENCING THE EVOLUTION OF INDICATORORS (COSTS AT 1000 RON TURNOVER)}

Evolution of indicators, expenditure at 1,000 RON turnovers takes place in the structure of turnover, the average selling price and unit cost of products. Structure of turnover worsens with increasing the rate of $25.87 \%$, average selling prices increased and a favorable effect on lowering its rate to $43.53 \%$, the unit cost is reduced and lowers costs 1,000 RON figure business to $134.45 \%$, favorable aspect for society, which compensates for the adverse outcome due to worsening of the structure turnover.

Modification costs 1,000 RON turnover is the consequence of the following factors, namely: material expenses (from 12.02 $\%$ to $13.84 \%$ o), energy costs and water (from $14.04 \%$ to 14.14 \%) cost of goods (from 205\% to $325.19 \%$ ), staff costs (from $123.75 \%$ o to $159.25 \%$ ), adjustment costs of current assets (from $0 \%$ to $2.45 \%$ ) and fixed tangible and intangible assets (from $2.99 \%$ to $6.66 \%$ ), which rose a total of $163.72 \%$, which offset the decrease of $291.24 \%$, both raw materials and consumables (from $540.82 \%$ o to $346.44 \%$ ) and the decrease in other operating expenses (from 216.59\%o to 119.73 \%) (Fig. 3).

A* - material expenses
$\mathrm{B}^{*}$ - energy costs and water

C*- cost of goods

D*- staff costs

$\mathrm{E}^{*}$ - adjustment costs of current assets

$\mathrm{F}^{*}$ - which offset the decrease of

$\mathrm{G}^{*}$ - decrease expenditure raw materials and consumables

Reducing costs of raw materials and direct materials is achieved by reducing material consumption per unit of product and their purchase price.

In terms of content these items of expenditure are differentiated on the industries in relation to a number of factors that generate production costs and in particular on the particular production technology and organization of industry.

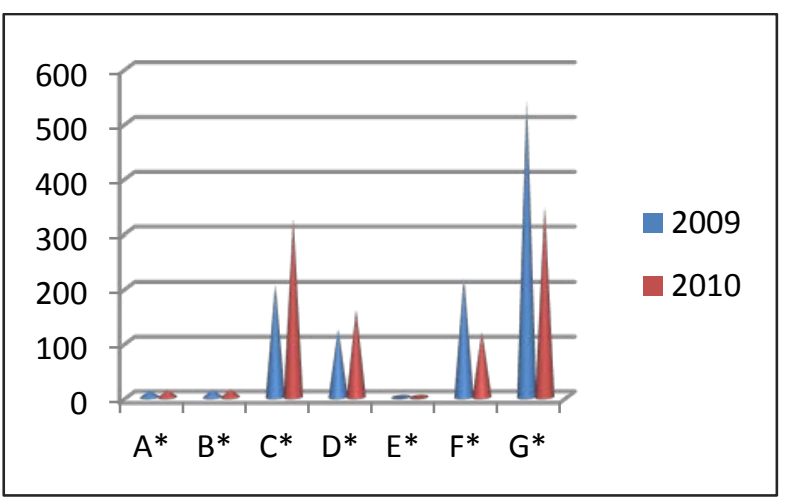

Fig.3. Evolution of indicators, spending 1000 RON turnover

\section{CONCLUSION}

Ideal for developing a company is when the cost per thousand RON turnover to decline, and efficient expenditure increased turnover, which means that the growth rate of turnover ahead of the growth rate of expenditure.

In the study we already reported that, for example, has reversed the relationship between costs and prices. Unlike this type of relationship, the market economy becomes the dominant indirect relationship between cost and price. Influences the cost price on the market made through the offer price included the cost of the product. Instead, the market price becomes an indirect role on costs forcing manufacturers to cut costs to increase profits. Direct competition between producers and competition generates indirect costs, earning more than those producers whose costs are lower.

\section{ACKNOWLEDGEMENT}

This work was partially supported by the strategic grant POSDRU/88/1.5/S/50783, Project ID50783 (2009), co-financed by the European Social Fund - Investing in People, within the Sectoral Operational Programme Human Resources

\section{REFERENCES}

Bailesteanu G., Diagnosis, risk and economic efficiency in business, Publishing, Mirton, 1998

Dumitrescu C.D. s.a, The general management elements, Publishing, Timisoara, 1998

Petrescu S., s.a, Finance economic analyse, Publishing, Iasi, 2002

Tamasila M., Performance analyze and the company diagnosis, Publishing Solness, Timisoara, 2008

Valceanu G., Robu V., Georgescu N., Finance economic analyse, Publishing, Economica, Bucuresti, 2005 